\title{
Yerel Yönetimler Ekonomisinde Yatay Eşitsizlik Sorununa ve Çözümüne Dair Teorik Bir Inceleme*
}

\section{A Theoretical Review on the Horizontal Inequality Problem and Solution in the Local Government Economics}

Berkan Karagöz ${ }^{1}$

RESEARCH

ARTICLE

\begin{tabular}{l} 
ARTICLE INFO \\
\hline Submitted : 14.10.2019 \\
Revised : 12.11 .2019 \\
Accepted : 17.12 .2019 \\
Available : 30.12 .2019 \\
\hline iThenticate similarity \\
score: $3 \%$ \\
\hline JEL classification: \\
H70, H72, H77 \\
\hline Keywords: \\
Local Government \\
Economics, Horizontal \\
Inequality, \\
Unconditional Transfers
\end{tabular}

\begin{abstract}
A B S T R A C T
The study examines theoretically the horizontal inequality problem of and its solution and seeks a theoretical solution to this problem. The horizontal inequality problem is a very important problem for the local public goods producer units in local government economics. Horizontal inequality means that the local public goods producer units have extra spending needs or the ability to find resources is different. The factors that cause horizontal inequality are demand effect, cost effect and overflow effect in terms of expenditure direction. In terms of tax capacity, the factors that cause horizontal inequality are shown as inter-regional income difference, the concentration of low-income groups and unwillingness to collect taxes. The horizontal inequality is determined in two ways as tax capacity and expenditure need directions. The solution of horizontal inequality requires the design of ideal horizontal fiscal relations programs between administrations and the equal utilization of public services by individuals living in disadvantaged areas. The unconditional transfers are referred to as the horizontal inequality transfer solvent type. However, the solution to the horizontal inequality problem can lead to various economic and fiscal problems. Therefore, the issue of a broad perspective should be taken into consideration when formulating public policy to solve horizontal inequality.
\end{abstract}

Cite this article as: Karagöz, B. (2019). "Yerel Yönetimler Ekonomisinde Yatay Eşitsizlik Sorununa ve Çözümüne Dair Teorik Bir İnceleme", International Journal of Public Finance, 4(2), 250-269.

\footnotetext{
* Ankara Üniversitesi SBE Maliye Anabilim Dalı’nda 04.12.2014 tarihinde savunulan ve jüri tarafından onaylanan "Mali Yerelleşme ve Yatay Eşitsizlik Sorunu: Türkiye Örneği” adlı doktora tezinden üretilmiştir.

${ }^{1}$ Assist. Prof. Dr, ORCID No: 0000-0002-7622-5113, Yozgat Bozok University, Department of Public Finance, Turkey, berkan.karagoz@bozok.edu.tr
} 
Karagöz, B. (2019). "Yerel Yönetimler Ekonomisinde Yatay Eşitsizlik Sorununa ve Çözümüne Dair Teorik Bir İnceleme", International Journal of Public Finance, 4(2), 250-269.

\begin{tabular}{|c|c|}
\hline MAKALE BİLGisi & ÖZET \\
\hline Gönderme: 14.10.2019 & \multirow{11}{*}{$\begin{array}{l}\text { Çalışma, yerel yönetimler ekonomisinde var olan yatay eşitsizlik sorunu ile } \\
\text { çözümünü teorik olarak incelemekte ve bu soruna teorik çözüm } \\
\text { aramaktadır. Yatay eşitsizlik sorunu, yerel yönetimler ekonomisinde yerel } \\
\text { kamusal mal üretici birimleri açısından oldukça önemli bir sorundur. Yatay } \\
\text { eşitsizlik, yerel kamusal mal üretici birimlerinin fazladan harcama } \\
\text { ihtiyaçlarının bulunması ya da kaynak bulabilme yeteneklerinin birbirinden } \\
\text { farklı olması anlamına gelmektedir. Yatay eşitsizliğe neden olan faktörler, } \\
\text { harcama yönü açısından talep etkisi, maliyet etkisi ve taşma etkisi; vergi } \\
\text { kapasitesi yönü açısından ise bölgelerarası gelir farklılığı, düşük gelirli } \\
\text { grupların yoğunlaşması ve vergi toplama isteksizliği olarak gösterilir. Yatay } \\
\text { eşitsizlik, vergi kapasitesi yönü ve harcama ihtiyacı yönü olmak üzere iki } \\
\text { yönlü olarak tespit edilir. Yatay eşitsizliğin çözümü, ideal idareler arası } \\
\text { yatay mali ilişki programlarının dizayn edilmesi ve dezavantajlı alanlarda } \\
\text { yaşayan bireylerin kamusal hizmetlerden eşit düzeyde yararlandırılmasını } \\
\text { gerektirir. Şartsız transferler, yatay eşitsizliği çözücü transfer türü olarak } \\
\text { gösterilir. Ancak yatay eşitsizlik sorununun çözümü çeşitli iktisadi ve mali } \\
\text { sorunlara neden olabilir. Bu yüzden yatay eşitsizliği çözücü kamu politikası } \\
\text { oluşturulurken geniş perspektiften konu ele alınmalıdır. }\end{array}$} \\
\hline Düzeltme : 12.11.2019 & \\
\hline Kabul $\quad: 17.12 .2019$ & \\
\hline Yayın $\quad: 30.12 .2019$ & \\
\hline $\begin{array}{l}\text { iThenticate benzerlik } \\
\text { oranı: } \% 3\end{array}$ & \\
\hline JEL Kodu: & \\
\hline $\mathrm{H} 70, \mathrm{H} 72, \mathrm{H} 77$ & \\
\hline Anahtar Kelimeler: & \\
\hline $\begin{array}{l}\text { Yerel Yönetimler } \\
\text { Ekonomisi, Yatay }\end{array}$ & \\
\hline Eşitsizlik, Şartsız & \\
\hline Transferler & \\
\hline
\end{tabular}

\section{Giriş}

Çalışma, yerel yönetimler ekonomisinde var olan yatay eşitsizlik sorunu ile çözümünü teorik olarak incelemekte ve yatay eşitsizlik sorununa çözüm aramaktadır. Yatay eşitsizlik sorunu, yerel yönetimler ekonomisinde yerel kamusal mal üretici birimleri açısından oldukça önemli bir sorundur.

Yerel kamusal mal üretici birimleri arasındaki yatay eşitsizlik, yerel kamusal mal üretici birimlerinin fazladan harcama ihtiyaçlarının bulunması ya da kaynak bulabilme yeteneklerinin birbirinden farklı olması anlamına gelmektedir. Vergi toplama kapasitesi aynı olan yerel birimlerden bazıları, bazı nedenlerle daha fazla kamu harcaması yapma eğilimi gösterebilir ve fazla kamu harcaması yaptığı miktar için mali eşitsizliğe düşebilir. Ya da yerel birimlerin kaynak bulabilme yeteneği birbirinden farklı olabilir. Söz konusu durumlarda yerel kamusal mal üretici birimleri arasında yatay eşitsizlik ortaya çıkar. Yatay eşitsizliğe neden olan faktörler, harcama yönü açısından talep etkisi, maliyet etkisi ve taşma etkisi; vergi kapasitesi yönü açısından ise bölgelerarası gelir farklıı̆̆ı̆, düşük gelirli grupların yoğunlaşması ve vergi toplama isteksizliği olarak gösterilir.

Yatay eşitsizlik sorununun çözümü için öncelikle yerel kamusal mal üretici birimleri arasındaki yatay eşitsizlik farkının ölçümlenmesi gerekmektedir. Ancak yatay eşitsizliği ölçmek oldukça zor ve karmaşık bir iştir. Yatay eşitsizliğin çözüm yöntemleri ülkeden ülkeye farklılık gösterdiğinden yatay eşitsizliğin çözümünü teorik çerçeveye oturtmak zordur.

Yatay eşitsizliğin büyüklüğünün ölçümü için bir yandan söz konusu yerel birimin vergisel kapasite farklılığının ortaya konması diğer yandan da yerel birimin harcama 
yönündeki farklılığının dikkate alınması gerekir. Bir konuda ölçüm yapabilmek sağlam istatistiki veriler gerektirir. Bu bakımdan sağlam istatistiki verilere sahip ülkeler açısından yatay eşitsizliği tespit etmek oldukça kolayken, sağlam istatistiki verilere sahip olmayan ülkeler açısından yatay eşitsizliği tespit etmek zordur.

Yatay eşitsizliğin tespit edilmesinden sonra, yatay eşitsiz olan yerel kamusal mal üretici birimleri için yatay eşitsizliği giderici veya azaltıcı ideal idareler arası yatay mali ilişki programlarının dizayn edilmesi gerekir. Avustralya ve Kanada transfer sistemleri, yatay eşitsizliği çözmede en ideal sistemler olarak gösterildiğinden, söz konusu ülkelerin yatay eşitsizlik çözüm programlarına benzer sistemler kurgulanmalıdır (Ma, 1997). Burada, sağlam istatistiki verileri olan ülkeler, yatay eşitsizlik programı kurgulamada daha avantajlı olacaklardır. Bunun yanında, yerel yönetimler ekonomisi teorisi, yatay eşitsizliği çözücü transfer türü olarak şartsız transferleri gösterir.

Yatay eşitsizlik sorununun bir transfer sistemi aracılığıyla çözümü kamu ekonomisinde başka çeşitli sorunlara neden olabilir:

-Kamu tercihi teorisine göre kamu ekonomisinde etkinsizlik ortaya çıkabilir.

-Şartsız transferler, yapılan transfer meblağından daha fazla yerel harcama yapılmasına neden olabilir.

-Yerel birimler ahlaki tehlike eylemlerine girişebilirler.

-Transfer sistemi vergiler ile kamusal mal tüketimi arasındaki bağı kopartır.

-Hesap verilebilirlik mekanizması olumsuz etkilenir.

-Mali illüzyon ortaya çıkabilir.

-Makroekonomik sorunlar yaşanabilir.

Bu yüzden yatay eşitsizliği çözücü kamu politikası oluştururken ortaya çıkabilecek bu sorunlar dikkate alınarak, iktisadi ve mali sorunlar yaratmayacak bir geniş perspektifle bir yatay eşitsizlik çözücü program oluşturulmalıdır.

\section{Yatay Eşitsizlik Kavramı}

Yatay eşitsizlik kavram olarak iki unsuru içerisinde barındırır. Birincisi, vergi toplama kapasitesi aynı olan yerel birimlerden bazıları bazı nedenlerle daha fazla kamu harcaması yapma ihtiyacı gösterebilir ve fazla kamu harcaması yaptığı miktar için mali eşitsizliğe düşebilir. Harcama ihtiyaçları fazla olan yerel birimler, ortalama standart bir hizmet sağlanması durumuna göre, daha fazla kişi başına düşen harcama yapan yerel birimlerdir (Ladd, 2005a: 143). İkincisi, yerel sakinlerin kamu harcamaları ihtiyacını karşılamada yerel birimlerin gelir kapasitesinin birbirinden farklı düzeylerde olması anlamına gelmektedir (Ladd, 2005a: 143). 


\subsection{Harcama İhtiyacı Yönünden}

Bir yerel birimin daha fazla harcama yapmasının birinci nedeni talep etkisidir (Tekeli, vd., 2005: 288). Talep etkisi; nüfus veya coğrafi büyüklük nedeniyle talepte meydana gelen artış veya azalış, nüfus kompozisyonu ve nüfusun sosyo-ekonomik farklılıkları nedeniyle talepte meydana gelen farklılaşma olarak tanımlanabilir. Örneğin, yaşlı nüfusun fazla olduğu bir yerel topluluğun harcama ihtiyacına etkisi ile öğrenci nüfusunun fazla olduğu bir yerel topluluğun harcama ihtiyacına etkisi farklı olabilir. Diğer bir ifadeyle yerel birimler arasında yüklenilmiş olan hizmet sorumluluklarında farklılaşmalar ortaya çıkmış olabilir. Talep ve teknoloji değiştikçe iktisadi etkinlik bireylerin daha üretken olabilecekleri yerlere gitmelerini gerektirir. Bu durum bazı bölgelerin azalan nüfusla, bazılarının da artan nüfusla karşı karşıya kalmalarıyla sonuçlanmaktadır (Stiglitz, 2000: 737). Nüfusun fazla olması ve sürekli artması söz konusu yerel birimin bir yandan vergi tabanının genişlemesi bir yandan da harcama ihtiyacının artması anlamına gelir. Kamu ekonomisinde azalan maliyet özelliği var olduğu düşünülürse artan nüfusun maliyetleri düşürdüğü de varsayılabilir (Grossman, 1987). Ancak genel kanı veya azalan maliyetler olmadığı varsayılırsa nüfustaki bir artışın kamu malına olan talebi arttırdığı yönündedir (Hyman, 1990: 639). Sürekli olarak nüfusun azalması, yerel birimlerin vergi kapasitelerini de olumsuz etkileyebilir. Ihtiyaç farklıı̆ı̆ını, sadece nüfus farklılığı (talep etkisi yönüyle) ile ölçülmesi doğru olmayabilir (Tekeli vd., 2005: 289).

Bir yerel birimin daha fazla harcama yapmasının ikinci nedeni maliyet etkisidir. Maliyet etkisinde, nüfus yoğunluğu, girdi maliyetleri, coğrafi şartlar, yönetim ölçeği, ölçek ekonomilerinin eksikliği, yerleşim etkinsizliği ve demografik özellikler nedeniyle harcama ihtiyacı maliyet yönünden farklılaşır. Nüfus yoğunluğu düşük olan yerler aynı hizmet seviyesini gerçekleştirmek için daha fazla kişi başına harcama gerektirir ve kişi başına düşen maliyet artar. Yerleşim etkinsizliği, belirli bölgelerde nüfusun yoğunlaşması anlamına gelmektedir ve düşük nüfus yoğunluğunun olduğu bölgeler harcama yönlü yatay eşitsizliğe neden olabilir. Söz konusu etkiler, harcama ihtiyacını arttıran kontrol edilemeyen maliyet faktörleridir. Yoksa yerel yönetimin kendi yönetim bozukluğundan kaynaklanan maliyet farklılığı, ihtiyaç farklıı̆ı̆ın tanımlanmasında dikkate alınmaz. Maliyet farklıı̆̆ı, aynı düzeyde harcama yapılmasına rağmen, aynı seviyede mal ve hizmet çıktısı elde edilmesine engel olur (Tekeli vd., 2005: 289).

Bir yerel birimin daha fazla harcama yapmasının bir diğer nedeni taşma etkisi adı verilen faktördür. Bir yerel yönetim eyleminin, diğer bir yerel yönetim üzerinde önemli etkisi varsa taşma etkisi nedeniyle yatay eşitsizlikten söz edilir. Burada bir yerel yönetimin komşu bir yerel yönetime olumsuz dışsallıklar yayan taşma etkisi söz konusuysa olumsuz dışsallıktan etkilenen yerel birimin kamusal harcama yükü artacaktır. Diğer yandan, bazı dışsalıklar komşu bölgelere olumlu etkiler de yayabilir (Bruce, 2001:553). Böyle bir durumda da kamusal harcama yükü, dışsallığı yayan yerel birim üzerinde kalacaktır. 


\subsection{Gelir Yönünden}

Yerel birimlerin gelir kapasitesinin birbirinden farklı düzeylerde olması, yerel kamusal mal üretici birimleri arasındaki yatay eşitsizliğin diğer bir kaynağıdır. Gelir kapasitesini belirleyen unsurların başında, yerel birimin bulunduğu bölgenin coğrafi ve iktisadi yeterliliği gelir. Bölgelerarası coğrafi ve iktisadi yeterlilik açısından farklılaşmalar ve bunun neden olduğu bölgelerarası gelir farklılığı, yerel birimlerin gelir kapasitelerini etkiler. Yörenin üretime yönelik temel altyapısı, teknolojik altyapısı, bilgi altyapısı, eğitim imkânları ve niteliği; altyapı yeterliliğini belirler. Bir yandan altyapı yeterliliği, diğer yandan demografik özellikler ve üretken çevre adı verilen yörenin girişimciliği, kurumsal kapasitesi, yönetişimi, sermayesi, inovasyonu, yerel politika üreticileri ve karar alma süreçleri birleşerek yörenin rekabet etme gücünü oluşturarak bölgesel farklılıkları ortaya koyarlar (Uzay, 2005: 67). Bölgesel farklılıklar, mali farklılığa neden olur. Bölgesel gelir düzeyinde ortaya çıkan farklılıklar nedeniyle aynı kademedeki yönetim birimleri arasında gelir kapasitesi farklılı̆ı meydana gelir (Due \& Friedlaender, 1977: 464). Coğrafi ve iktisadi yeterliliğe sahip yerel birimler daha yüksek düzeyde gelir toplarken söz konusu özellikleri taşımayan yerel birimler düşük gelir düzeyinde kalmaktadırlar (Yılmaz, 2003: 7). Bazı yörelerin doğal kaynak geliri gibi ekstra gelirlere sahip olması bölgelerarası gelir farklılıklarının derinleşmesine neden olur (Litvack \& Seddon, 2004: 86).

Dengesiz bölgesel büyüme modelleri, bölgesel gelirlerin kendi kurallarına bırakıldıkları takdirde, alansal olarak dengesizleşmeye neden olan piyasa güçlerinden dolayı birbirinden uzaklaşma eğilimi göstereceğini iddia etmektedir (Martin \& Sunley, 1998: 201). Uzaklaşma modellerinin temelini oluşturan bu görüşe göre, ölçek ekonomileri ve alansal yı̆̆ılma nedeniyle devlet müdahalesi olmadığı sürece sermaye, emek, mal ve hizmet üretimi diğer bölgelerin aleyhine kümülatif olarak bir birikim gösterir (Öztürk, 2006: 23). Neoklasik teoriye göre ise, bölgesel eşitsizlik kısa dönemde ortaya çıkacaktır. Teknolojinin bölgelerarasında benzer varsayıldığı ölçeğe göre sabit getiri koşullarında homojen olan sermaye ve iş gücü, kendilerine en yüksek getiriyi sağlayan bölgelere göç edecektir. Üreticiler fabrikaları için en kazançlı alanları ararken tam istihdamın söz konusu olduğu bölgelerde işçiler de ücretlerin yüksek olduğu yerlere doğru çekilecektir; böylelikle bölgesel eşitsizlikler yalnız tasarruflar ve nüfustaki artış, yani emek ve sermayenin içsel büyüme oranlarındaki farklılıklardan değil ayrıca kısa dönemde bölgelerarası faktör göçünden dolayı da ortaya çıkabilmektedir. Kısa dönemde görülen bu gelişmeler uzun dönemde faktör fiyatları, dolayısıyla gelirlerin bölgelerarasında eşitlenmesiyle son bulacaktır; yani bölgelerarasında görülen büyüme farklııkları kaynakların bölgelerarası tahsisi süreciyle gittikçe azalacak ve belirli bir uzun dönem değerine ulaşacaktır (Öztürk, 2006: 25).

Bölgelerarası gelir farklılı̆̆ının arkasında bölgelerarası gelişmişlik farkı sorunu bulunmaktadır. İçsel ve dışsal ekonomiler sonucu bir bölge giderek gelişirken diğer bölgeler benzer bir gelişme gösterememekte, kaynaklarını gelişmekte olan bölgelere kaptırmaktadır (Özel, 2009: 166). 
Nüfusunun büyük bir kısmının düşük gelirlerin oluşturduğu bir yerel topluluk, yüksek gelirli yerel topluluğa göre standart kamu malı demetinin sağlanmasında dezavantajlara sahiptir. Düşük gelirli grup, yerel birimin kaynağının sınırlı olması anlamına gelir. Düşük gelirli insan yoğunluğu diğer yerel birimlere göre, standart kamu malı demetinin sağlanmasında daha fazla kişi başına harcama yapılmasını gerektirebilir (Ladd, 2005a: 143). Düşük gelirli insanların olduğu bir yerel birimde, zengin bir yerel birimin sunduğunun aynısı olan hizmetleri sunmak çok daha yüksek vergi oranını gerektirir. Ortalamanın üzerinde mali kapasiteye sahip bir büyük şehir sahip olduğu nüfusa göre, mali açıdan avantajlı konumda olabilir. Ancak şehir üzerindeki yüksek harcama yükünün şehrin düşük gelirli nüfusu üzerinde olduğu ve banliyölerden gelen veya ticaret için şehre akın edenler olduğu dikkate alındığında şehrin mali şartları olumlu olmayabilir (Ladd, 2005a: 144).

Vergi toplama isteksizliği mali farklılaşmaya neden olabilmektedir (Sağbaş \& Bağdigen, 2003: 136). Yerel birim bünyesindeki bireylerin vergi bilinç düzeyi, yerel birimin vergi ahlakı ve vergi toplama gayreti, mali kaynakların oluşmasında belirleyicidir.

\section{Yatay Eşitsizlik Sorununun Çözümü}

Yatay eşitsizlik sorununu çözümünde, soruna yönelik kamu politikası oluşturulur. Kamu politikaları, mali açıdan zayıf veya harcama ihtiyacı yüksek bölgelerin sorunlarını çözmede rol oynar. Söz konusu kamu politikası, eşitlik sağlayıcı transfer sisteminin geliştirilmesidir. Yatay eşitsizlik sorununun çözümü, ideal idarelerarası yatay mali ilişki programlarının dizayn edilmesini gerektirir. Mali federalizm teorisine göre; regülatif fonksiyona haiz bir merkezi yönetimin tesisi ile yatay eşitsizlik sorunu aşılabilir. Diğer bir anlatımla, kamu ekonomisinin özel piyasa kuramlarından alması ve içselleştirmesi gereken ödünç kurum "regülasyon" kurumudur. Zira yatay eşitsizlik, merkezi hükümet müdahalesini gerektiren bir husustur (Bruce, 2001: 565). Merkezi hükümet yerel birimin finans ihtiyacını karşılamaya ve kapasitesini aşan harcama ihtiyaçların finansını tamamlamaya çalışır ve mali sistemi düzenler.

Mali eşitleme politikalarının gerek etkinlik gerekse adalet sağlama açısından haklı tarafları vardır. Bir kamusal programın değerlenmesi, programın iktisadi etkinlik ve gelir bölüşümü açısından etkilerini dengelemeyi gerektirir. Etkinlik açısından mali eşitleme politikalarının mobil vergi tabanı etkinsizliğini azalttığı belirtilmektedir. Firmaların yerleşme ve yatırım kararlarında yerel birimin mali yetersizliği firmayı olumsuz etkiliyorsa yatay eşitleme politikası, firmaların mali yetersizliği olan yerel birimlere de taşınmasına neden olur (Ladd, 2005b: 145). Diğer yandan, yatay eşitleme politikaları yeni çarpıklıklara neden olabilir. Yoksul ya da yüksek maliyetle kamusal mal üreten yerel birimlere yapılan yardımlar, söz konusu yerel birimlere yönelecek göçleri olumsuz etkileyebilir (Ladd, 2005b: 145). Mali eşitleme politikalarının adalet sağlama açısından güçlü argümanları vardır. Ülkenin sadece belirli bir kısmında toplanmış olan 
doğal kaynakların ve ekonomik avantajların ülke genelindeki yerel birimler arasında dengeli bir şekilde kullanımında yatay eşitleme politikası önemli fonksiyona sahiptir. Bu açıdan yatay eşitleme politikaları eşitlik sağlayıcıdır (Ladd, 2005b: 145).

Transfer mekanizması gelirin yeniden dağıtımı rolüne (redistribution) sahiptir. Bir yerel birime yapılan transfer, ilgili birimde yaşayan bireylerin vergi indirimi yaşaması anlamına gelir. Bu yüzden topluluğun özel gelirinin yapılan transfer miktarı kadar artması gerekir (Oates, 1999: 1129). Transfer mekanizmasına yönelik uygun gelir dağılımının ne olduğu konusu ile ilgili verilecek karar için siyasal karar alma mekanizmasına başvurulması gerekmektedir. Merkezi yönetim tarafından yapılan sosyal harcamalar gelir dağılımını düzeltmede birincil fonksiyona sahipse de transfer mekanizması da gelir dağılımını düzenleyici bir fonksiyona haizdir (Musgrave, 1959).

Transfer mekanizması yoluyla zengin bir yöreden alınan kaynaklar, yoksul bölgeye aktarılıyorsa adalet artıyor demektir. Neoklasik paradigmaya göre, zengin yörelerin durumunu kötüleştirmeden düşük ve orta gelirli yörelerin iyi duruma getirilmesi gerekmektedir. Bir politikanın sebep olduğu değişmeler çoğunlukla karmaşıktır. Zengin bölgelerden, düşük ve orta gelirli yörelere kaynak aktarılırken etkinlik kaybı en az düzeyde olmalıdır. Transfer sisteminin nasıl olması gerektiği konusunda bireyler kendi görüşlerini temsil ettiği partilere oy vererek adalet anlayışını gösterebileceklerdir.

\subsection{Yatay Eşitsizliğin Tespiti ve Ölçümü}

Yerel kamusal mal üretici birimleri arasında yatay eşitsizliğin çözümü için öncelikle, mukayese yapılabilmesi için yatay eşitsizliğin tespiti ve ölçümü gereklidir.

Bir yerel birimin yatay eşitsiz konumda olup olmadığı gerek harcama yönünden gerekse gelir yönünden mali şartları incelenerek ortaya konur. Vergi toplama kapasitesine bakmadan sadece harcama yönünü dikkate alma hatası, mali şartları belirlemede yanlış yönlendirici olabilir. Örneğin, metropol şehirlerin mali şartlarının ölçümlenmesi oldukça zor ve önemlidir. Çünkü metropollerdeki iş ve ev banliyöleşmeleri, ilgili yerel birimin vergi tabanını azaltmakta ve yoksul kesimlerin ilgili yerel birimle olan ilişkilerini arttırmaktadır. Yerel mali şartların ölçümünde, yerel yetkililerin kontrolü dahilinde olduğu faktörler ve olası münferit müdahaleleri olabilecek faktörler ölçüme dahil edilmemelidir (Ladd, 2005a: 144).

\subsubsection{Harcama Yönü}

Harcama ihtiyaçları farklı olan yerel birimler, yatay eşitsiz birimlerdir ve harcama ihtiyaçları farklı olan yerel birimlerin tespit edilmesi gerekir. Harcama yönünün ölçümü, yerel harcama ihtiyacında farklılığa neden olan faktörlerin ortaya çıkarılmasına dayanır. 
Birinci yaklaşım, standart harcama yaklaşımı ile tavsiye edilen standartların gerçekleştirilmesi durumunda ortaya çıkan talep ve maliyet yönlü ihtiyaç farklılığının tespit edilmesidir. Standart harcama yaklaşımı, yerel birimlerin ihtiyaç farklılığına göre sıralanmasına izin verir (Tekeli vd., 2005: 289). Ancak standart harcama ihtiyacının belirlenmesi yerel birimlerin öncelik sıralamasına göre yaptığı kamusal üretimi dikkate almaz.

Maliyet farklılığının olmadığı varsayılırsa yerel birimlerin kişi başına düşen harcamalarının eşit olması gerektiği üzerinde durularak ülke ortalaması ile yerel birimin kişi başına düşen harcaması arasındaki fark hesaplanabilir. Burada ülke ortalaması standartlaştırılmış harcamadır. Her bir fonksiyonel harcama kalemi için ayrı ayrı hesaplanabileceği gibi toplam yerel harcamalar açısından da standartlaştırılmış harcama tutarı belirlenebilir. Bu durumda iş yükü fazla olan bir yerel birim, başka bir yerel birimine göre daha fazla harcama ihtiyacı duyacaktır (Ladd, 2005a: 144). Söz konusu fark, harcama yönünden yatay eşitsizlik belirtisidir. Ortalamadan sapma arttıkça yerel birimler arasında eşit olmayan bir kamusal üretimin olduğu sonucuna ulaşılır.

İkinci yaklaşım, harcama ihtiyaçlarına yönelik özel belirleyiciler kullanmaktır (Shah, 2007: 24). Korelasyon analizi ile harcamalardaki değişmenin nedenleri ortaya konabilir. Ya toplam harcamalar ya da belli bir hizmet için yapılan harcamalardaki değişimin nedenleri analiz edilir. Maliyet etkili nedenler ve talep etkili nedenler açıklayıcı değişkenler olarak analize dâhil edilir. Korelasyon analizi sonucunda anlamlı çıkan katsayılar ihtiyaç göstergesi olarak kullanılabilir. intiyaç gösterge değerleri sıralanarak, belirli bir değerin altında veya üstünde gösterge değerine sahip yerel kamusal mal üretici biriminin ihtiyaç yönünden yatay eşitsiz olduğu kabul edilecektir. Uygulamada kullanılan bazı ihtiyaç göstergeleri şunlardır (Shah, 2007: 24; Ma, 1997: 35-36):

- Nüfus

- Nüfus Yoğunluğu

- Yol Uzunluğu

- Yerleşim Birimi Sayısı

- Yer Faktörleri (Yerel birimin kuzeyde olması, dağlık olması gibi)

- Sosyal Faktörler (Öğrenci sayısı, yaşlı sayısı)

- Kentleşme Faktörleri

- Kamu Çalışanı

- Kişi Başına Düşen Gelir Düzeyi

- Yoksulluk Oranı

- İşsizlik Oranı

- Yüzölçümü 
- Bebek Ölüm Oranı

- Yaşam Süresi

- Okullaşma Oranı

- Çeşitli Altyapı Göstergeleri (Karayollarının uzunluğu gibi)

- Kalkınmışlık Düzeyi Göstergeleri (Elektrik tüketimi, telefon hattı sayısı gibi)

Üçüncü yaklaşım, regresyon analiziyle maliyet endeksleri geliştirmektir. Bu yaklaşıma "temsili harcama sistemi" adı verilir. Yerel harcamalar çeşitli fonksiyonlara göre ayrılır. Her fonksiyon için her bölgenin toplam harcaması gerçekçi bir şekilde belirlenir. İlgili ihtiyaç-maliyet faktörleri tanımlanır. Kullanılacak ağırlıklar regresyon modelleriyle belirlenir (Shah, 2007: 25). İlgili yerel birimin ortalama bir yerel birimin maliyetinden farkı, söz konusu yerel birimin karakteristik maliyetini ortaya koyar. Maliyet endeksleriyle harcamalardaki değişimlerin gerçek nedenleri ortaya koyulmaya çalışııı. Örneğin, ücret farklıığı, kira maliyetindeki farklııklar, düşük gelirli aile çocuk endeksi eğitim alanında yerel birimler arasında maliyet farkı yaratır. Bu yaklaşım, kamusal mal üretimindeki talepsel farklılıkları ortaya koyduğu kadar maliyet farkını da ortaya koymada başarılı bir yöntemdir (Ladd, 2005a: 144). Maliyet endekslerine dayalı olarak belirlenen faktörler, mali yardım politikasına objektiflik kazandıır. Diğer yandan, temsili veri kullanımından doğan problemler bertaraf edilmiş olur. Temsili harcama sistemi aşağıdaki gibi formüle edilebilir (Shah, 2007: 22):

EExi $=(P O P) x[(P C S E) i x-(P C S E) i n a]$

EExi : $x$ yerel yönetimin harcama ihtiyacı

(POP)x: $x$ yerel yönetimin nüfusu

(PCSE)ix: $x$ yerel yönetiminde kişi başına düşen standardize edilmiş harcama

(PCSE)ina: ulusal kişi başına düşen standardize edilmiş ortalama harcama

Kişi başına düşen harcama ise örneğin şu şekilde tespit edilebilir (Shah, 2007: 22):

$(P C S E)_{X}^{i}=$ Standart Harcama X [(Ulaşım Endeksi X Ağırlık $\left.{ }_{1}\right)+($ Eğitim Endeksi $X$ Ağırlık $\left.{ }_{2}\right)+($ Sağlık Endeksi X Ağırıık $)+($ Sosyal Harcama Endeksi X Ağırlık 4$)+($ Genel Kamu Hizmeti Endeksi X Ağırlık $\left.)_{5}\right]$

Ulaşım endeksi, kar yağışlı gün sayısı, otoyol inşaat fiyatı, km2ye düşen asfalt yol; eğitim endeksi, 18 yaş altındaki nüfus, nüfus yoğunluğu, eğitim fiyatı, azınlık dili konuşanların oranı; sağlık endeksi, kentsel nüfus yoğunluğu, bebek ölüm oranı, yaşlı nüfus; sosyal harcama endeksi, tek ebeveynli aile sayısı, çocuk esirgeme kurumlarında bulunan nüfus, yoksul nüfus; genel kamu hizmeti endeksi, nüfus, nüfus yoğunluğu, bölgenin coğrafi yapısı, bölgenin iklimi dikkate alınarak hesaplanabilir (Shah, 2007: 22 vd.). 


\subsubsection{Vergi Kapasitesi Yönü}

Vergi tabanını belirlemeye yönelik sağlam verinin olmadığı ülkeler için yerel birimde kişi başına düşen gelirin veya kişi başına düşen gayrisafi yurt içi hasılanın tespit edilmesi, vergi toplama kapasitesinin belirlenmesinde en basit yoldur ${ }^{2}$ (Shah, 2007: 22). Eğer kişi başına düşen gayrisafi yurt içi hasıla, ortalamanın veya belirli bir değerin altındaysa, o yerel birim yatay eşitsizliğe sahiptir. Ancak kişi başına düşen gayrisafi yurt içi hasıla gibi makro ölçüler, vergi toplama kapasitesini tam yansıtamayacağı yönünde eleştirilir (Shah, 2007: 22).

Diğer bir yöntem, literatürün de üzerinde önemle durduğu yerel birimlerin vergi tabanlarındaki farkııı̆ın tespiti için ekonomik mikro veri kullanılmasıdır. Bu yönteme genelde "temsili vergi sistemi" adı verilir (Shah, 2007: 22). Bu sistemde, kişi başına düşen vergi (veya daha geniş anlamda kamu alacağı) toplayabilme kapasitesi ağırlıklı ortalamayla tespit edilen potansiyel kişi başına düşen vergi tabanının hesaplanmasıyla belirlenir. Ağırlıklar her vergi için ortalama vergi oranıdır. Bu yaklaşım, bir yerel birimin potansiyel vergi tabanından ortalama bir vergi oranında ne kadar vergi alacağı topladığını ortaya koyar ${ }^{3}$. Ancak bu yaklaşım, ortalama vergi oranının vergi tabanı üzerindeki davranışsal etkilerini veya yerel sakinler üzerindeki zımni yüklerini dikkate almaz. Diğer yandan tanımlanması gereken durumu kolayca ortaya koyması, vergi tabanı ile bağlantı kurması ve iktisatçı olmayanların vergi toplama kapasitesi ile ilgili durumu anlayabilmeleri güçlü yönleridir (Ladd, 2005a: 144).

\subsection{Transfer Sisteminin Formülasyonu}

Birinci formülasyon türü; güvenilir veriye bağlı olarak hem vergi toplama kapasitesi hem de harcama ihtiyaçları baz alınarak transfer formülü belirlenmesidir. En ideal yatay eşitsizliği çözücü transfer sisteminin olduğu ülke olarak gösterilen Avustralya'nın böyle bir transfer formülü vardır (Ma, 1997). Burada formül; $T R_{i}=N_{i}-C_{i}$ - OTR $_{i}$ şeklinde basitleştirilebilir. Burada $T_{i}$ yapılacak transfer miktarını; $N_{i}$ harcama ihtiyacını; $C_{i}$ vergi toplama kapasitesini; OTR $_{i}$ yapılan diğer transferleri sembolize etmektedir. Burada i yerel birimi tanımlamaktadır. Ortaya çıkan ve hesaplanan transfer hakkı toplamına $\left(\sum_{\mathrm{i}} \mathrm{TR}_{\mathrm{i}}\right)$ denk bir miktar belirli bir havuzda toplanan gelirlere göre nasıl dağıtılacağı konusu önemlidir. Çünkü havuz toplam hesaplanan transfer hakkından daha küçük veya daha büyük olabilir. Yaygın olarak kullanılan yöntem, havuzun büyüklüğüne göre transfer hakkını orantılı bir şekilde dağıtmaktır: $\left[A T R_{i}=\left(T T / \Sigma_{i} T R_{i}\right) T R_{i}\right]$

\footnotetext{
2 Sağbaş ve Bağdigen (2003), vergileme kapasitesi açısından yerel birimler arasındaki farklılıkların nedenlerini incelemiştir. Sağbaş \& Bağdigen (2003), vergileme kapasitesini etkileyen değişkenlerin kişi başına yerel gayrisafi yurt içi hasıla, kişi başına düşen gelir ve kurumlar vergisi, sınai, ticari ve mali sektörde çalışan sayısı, turizm ve ticaret merkezi olma özelliği taşıma, bağımlı yaş oranı ve kentleşme oranı olduğunu belirlemiştir. Bağımlı yaş oranı ve kentleşme oranı vergileme kapasitesi ile ters orantılıyken diğerleri doğru orantılıdır. Tekeli vd., (2005) çalışmasında, kişi başına bölgesel gayrisafi yurt içi hasıla değerini mali kapasite göstergesi olarak kullanmıştır.

${ }^{3}$ Bu tür bir sistem hem vergi oranlarının tektipliği hem de yerel vergi tabanına ilişkin veri eksikliği nedeni ile Türkiye'de uygulanabilir değildir (Neyaptı, 2005: 108).
} 
$\mathrm{TT}$ havuzun boyutunu, $\sum_{\mathrm{i}} \mathrm{TR}_{\mathrm{i}}$ hesaplanan toplam transfer hakkını, ATR $\mathrm{R}_{\mathrm{i}}$ aktarılacak transfer miktarını göstermektedir (Ma, 1997).

İkinci formülasyon türü, sadece vergi toplama kapasitesi dikkate alınarak transfer formülü ortaya konmasıdır. Bu sistemi en iyi kurgulayan ülkelerden biri Kanada'dır (Ma, 1997). Bu tür formülasyonda harcama ihtiyaçları için veriye gereksinim duyulmaz. Tüm yerel birimlerin aynı harcama ihtiyacı içinde oldukları varsayılır. Söz konusu formülün tipik bir örneği şudur ve Kanada'da bu formülasyona "temsili vergi sistemi" adı verilir. Formül; $T R_{i}=P_{i}\left(B / P-B_{i} / P_{i}\right) t$ şeklinde basitleştirilerek yazılabilir. Burada $\mathrm{P}_{\mathrm{i}}$, yerel birimin nüfusunu, $\mathrm{B}_{\mathrm{i}}$ yerel birimin vergi tabanını, $\mathrm{P}$ ülkenin toplam nüfusunu, B ülkenin toplam vergi tabanını, $t$ ülkenin vergi tabanı üzerindeki ortalama efektif vergi oranını sembolize etmektedir. Bu transfer formülasyonuyla vergi toplama kapasitesi açısından ulusal ortalamanın altında kalan yerel birimler ulusal ortalamaya çekilecektir. Kanada'da ortalamanın altında kalan yerel birimler merkezi yönetimden transfer almakta, ortalamanın üstünde kalan yerel birimler merkezi yönetimden transfer almamaktadır. Ancak transfer için ortalamanın üstünde kalan yerel birimlerin havuza katkısı söz konusu değildir (Ma, 1997; Tekeli vd., 2005: 284).

Üçüncü yol, herhangi bir formülasyon geliştirmeyip sadece ihtiyaç göstergeleri üzerinden bir transfer sistemi kurgulamaktır. Hem harcama ihtiyacının hem de vergi toplama kapasitesinin belirlenemediği ülkelerde sadece harcama ihtiyacı göstergeleri üzerinden transfer yapılır. Hindistan, İtalya ve İspanya sadece harcama ihtiyacı göstergeleri üzerinden yatay eşitliği sağlayan ülkelere örnektir. Burada, yerel birimlerin ihtiyaçlarını yansıtacak göstergelere ihtiyaç vardır. Hangi göstergelerin seçileceği ve hangi göstergelerin ne kadar ağırlıkta alınacağı ülkenin yapısı ve yerel özellikler dikkatle incelenerek belirlenmelidir (Ma, 1997).

Dördüncü yol ise sadece nüfus kriteri kullanılarak kişi başına düşen transfer miktarının hesaplanmasıdır. Diğer üç yönteme göre en zayıf olanıdır. Yerel birimlerin ne kadar transfere intiyacı olduğu belirsizdir. Gerekenden fazla transfer alabilecekleri gibi gerekenden az transfer almakta da olabilirler. Nüfus kriterine dayalı transfer, yatay eşitsizliği tamamen giderici bir özelliğe sahip değildir, sadece bölgesel eşitsizliğin azaltılmasına yardımcı olabilir (Ma, 1997: 36).

\subsection{Transfer Türünün Tespiti}

Yatay eşitsizliği giderici veya azaltıcı eşitleme programı için yatay eşitsizlik miktarı ve transfer yöntemi belirlendikten sonra yapılması gereken teoriye göre, transfer türünün belirlenmesidir. Uygulamada görülen iki transfer türü vardır: a) Şartsız transfer, b) Şartlı transfer.

Şartsız transferlerin varlık nedeni yatay eşitsizlik sorununu çözmektir (Due \& Friedlaender, 1977: 460; Tablo 1). Şartsız transferler, herhangi bir kamusal mal üretimine özgülenmemiş, nasıl harcanması gerektiği belirlenmemiş veya minimum düzeyde üretilmesi gereken herhangi bir kamusal mal için kullanma şartı olmaksızın 
yerel birimlerce kullanılan kaynaklardır. Şartsız transferlerde herhangi bir harcama alanında minimum harcama şartı beklenmez. Yerel birim herhangi bir yasal zorunluluğa bağlı olmaksızın kendi idaresiyle harcamada bulunur. Bu tür hibeler, yerel birimde yaşayan sakinler açısından vergi indirimi özelliği gösterebilir. Hizmetlerin finansmanında yerel halkın vergi yükünün ağırlaşması önlenmektedir (Litvack \& Seddon, 2004: 27).

Teoriye göre, şartsız transferler ${ }^{4}$ mali eşitlemeyi sağlamak için uygun bir araçtır (Oates, 1999: 1127). Yüksek mali ihtiyaca sahip ancak mali kapasitesi yetersiz olan yerel birimlere zengin yerel birimlerden fon aktarılır.

Tablo 1: Transfer Türleri ve Örnek Ülke Uygulamaları

\begin{tabular}{|l|l|l|l|}
\hline \multicolumn{1}{|c|}{ Transfer Nedeni } & \multicolumn{1}{|c|}{ Transfer Türü } & \multicolumn{1}{|c|}{ lyi Örnek } & Sakınılması Gereken \\
\hline $\begin{array}{l}\text { Bölgesel mali } \\
\text { farklıı̆̆ı azaltmak }\end{array}$ & $\begin{array}{l}\text { *Şartsı transfer } \\
\text { *Mali kapasite eşitleme } \\
\text { transferi }\end{array}$ & $\begin{array}{l}\text { Avustralya, Kanada ve } \\
\text { Almanya mali eşitleme } \\
\text { programları }\end{array}$ & $\begin{array}{l}\text { Çok faktöre dayalı gelir } \\
\text { paylaşımı sistemi }\end{array}$ \\
\hline $\begin{array}{l}\text { Fayda taşmasını } \\
\text { dengelemek }\end{array}$ & $\begin{array}{l}\text { *Açık uçlu eşleme transferi } \\
\text { (yararları dışarı çıkaran bir } \\
\text { eşitleme oranı) }\end{array}$ & $\begin{array}{l}\text { Güney Afrika'da eğitim } \\
\text { hastanelerine yapılan } \\
\text { transferler }\end{array}$ & \\
\hline $\begin{array}{l}\text { Ulusal minimum } \\
\text { standardı sağlamak }\end{array}$ & $\begin{array}{l}\text { *Şartlı blok transferler (hizmet } \\
\text { standardında şartlara dayalı) }\end{array}$ & $\begin{array}{l}\text { Endonezya yol ve ilköğretim } \\
\text { transferleri; Şili, Kolombiya ve } \\
\text { Güney Afrika eğitim transferleri }\end{array}$ & $\begin{array}{l}\text { Harcamaya dayalı şartlar belirleme; geçici } \\
\text { transfer }\end{array}$ \\
\hline $\begin{array}{l}\text { Ulusal önceliklerin } \\
\text { olduğu alanlarda } \\
\text { yerel öncelikleri } \\
\text { etkilemek }\end{array}$ & $\begin{array}{l}\text { *Açık uçlu eşleme transferi } \\
\text { (tercihen mali kapasite ile ters } \\
\text { orantılı olarak eşleme oranı) }\end{array}$ & $\begin{array}{l}\text { Kanada-sosyal hizmetlere } \\
\text { yönelik transferler }\end{array}$ & Geçici transfer \\
\hline
\end{tabular}

Kaynak: Litvack \& Seddon, 2004: 30.

Transfer öncesi ve transfer sonrası durumu gösteren Şekil 1'de, hem şartsız transferlerin hem de şartlı transferlerin ekonomik etkisi ortaya konmaktadır. Şekilde transfere konu olan kamusal mal $X$, diğer kamusal mallar ve tüm özel mallar $Y$ ile gösterilmiştir. $l_{2}$ farksızlık eğrisi, $l_{1}$ farksızlık eğrisine göre daha yüksek bir refah sunar. $A C$ ve $B D$ eğrileri maksimum $X$ ve $Y$ miktarını gösteren yerel kamusal mal üretici birimin alternatif bütçe doğrularıdır. $X$ ve $Y$ 'nin fiyatlarının sabit olduğu varsayılır. Eşitlik, bütçe doğrusu ile farksızlık eğrisinin kesiştiği bir noktada ortaya çıkar (Marjinal dönüşüm oranının marjinal ikame oranına eşit olduğu nokta). Şekilde $A B$ veya $C D$ miktarında şartsız transfer yerel birim tarafından alınmıştır. AC transfer öncesi bütçe doğrusu, BD transfer sonrası bütçe doğrusunu gösterir. Bütçe doğrusunun paralel bir şekilde kaymasının sebebi, şartsız transferin $X$ ve $Y$ mallarının ilgili fiyatlarında bir değişikliğe neden olmamasıdır.

\footnotetext{
${ }^{4}$ Geleneksel görüşe göre, şartsız transferler sadece gelir etkisine sahiptir. Şartsız transferler yerel birim sakinlerine yapılan doğrudan yardıma eşdeğer etkilere sahiptir (Stiglitz, 2000: 752).
} 


\section{Şekil 1: Şartsız ve Şartlı Transferlerin Ekonomik Etkisi}

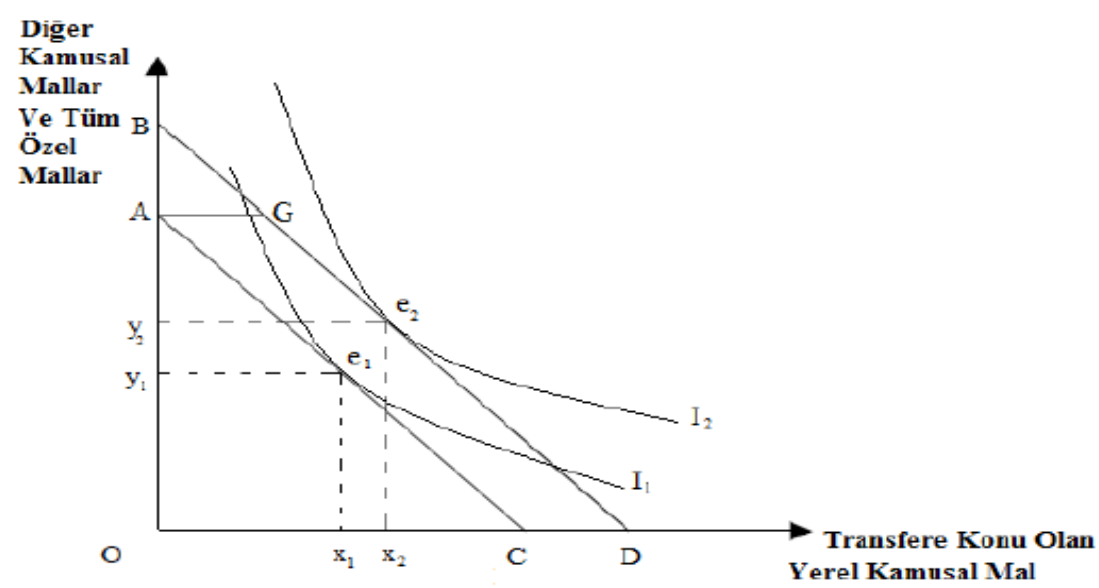

Kaynak: Bailey, 1999: 186.

Transfer öncesi $\mathrm{x}_{1}$ kadar $\mathrm{X}$ tüketilirken, $\mathrm{y}_{1}$ kadar $\mathrm{Y}$ tüketilmekte ve denge noktası $\mathrm{e}_{1}$ olmaktadır. Transfer sonrası ise $\mathrm{x}_{2}$ kadar $\mathrm{X}$ tüketilirken, $\mathrm{y}_{2}$ kadar $\mathrm{Y}$ tüketilmektedir. Burada denge noktası $e_{2}^{\prime}$ dir. Medyan seçmenin eğilimi $e_{2}^{\prime} y e$ kayar. Bu denge, yerel malla ilgili daha yüksek düzeyde bir harcama yapılması ve diğer kamusal mallar ile özel malların kişi başına tüketim düzeyinin yükselmesi anlamına gelmektedir. Şartsız transferler ile kamu harcamaları, öz gelirlerdeki artışın etkisinden daha çok miktarda bir artışla sonuçlanacaktır ${ }^{5}$. Ancak, kamu harcamalarındaki artış, şartsız transferden daha az miktarda bir artışa neden olur. Şartsız transfer, bireylerden alınan vergi oranının düşmesi anlamına gelmektedir. Diğer bir ifadeyle, yerel vergilemede azalma meydana gelir (Stiglitz, 2000: 744). Bunun anlamı, yerel birime yapılan transferin politik, teknik veya bürokratik nedenlerle yerel harcamalarda, özgelir kaynaklı meydana gelen harcama artışından daha fazla harcama artışına neden olmasıdır (Litvack \& Seddon, 2004: 27; Bailey, 1999: 233).

Şartsız transferler, yerel birimlerin kamusal mal üretimini gelir etkisi ve fiyat etkisi açısından uyarır. Söz konusu uyarma, yapılan şartsız transfer nedeniyle yerel topluluğun öz gelirlerinin toplanması gayreti üzerindeki olumsuz etki meydana gelmesiyle (gelir etkisi) ve/veya transfer nedeniyle yerel birimin ürettiği kamu malıyla ilgili ortalama fiyatların azalmasıyla (fiyat etkisi) meydana gelir. İkame etkisi ise, transferlerin öz gelirlerin yerine geçmesi olarak tanımlanmaktadır (Dahlby, 2011: 307). Yerel harcamaları uyarmak için ödenen transfer, özel sektör çıktılarına yönelik

\footnotetext{
${ }^{5}$ Bu etkiye sinek kağıdı etkisi denir. Şartsız transferlerin öz gelirlerdeki götürü bir artışla aynı etkileri doğuracağı iddiası yanlış olabilir. Şartsız transferlerin varlığı halinde seçmenler, kamu harcamalarının gerçek marjinal fiyatını algılayamazlar. Marjinal maliyetler, ortalama maliyetleri aşar ve seçmenler ortalama maliyeti, marjinal maliyete göre daha fazla fark eder. İkincisi, kısa dönemde kamu bürokratlarının bütçeler üzerinde önemli etkileri vardır. Eğer bürokratların ek fonları olursa, seçmenler bunu hemen öğrenemezler ve öğrenmiş olsalar dahi fonu kendilerine aktaracak yaptırım araçları yoktur (Stiglitz, 2000: 748; Holcombe, 2006: 494).
} 
harcamaları da uyarabilir. Aynı zamanda, yerel harcamaları uyarmak için ödenen transfer, yerel vergilendirmenin azalmasına zemin hazırlayabilir (Bailey, 1999: 184). Transferler, transfer yapılan bölgede ev fiyatlarını arttırabilir. Ancak bu konu tartışmalıdır (Ladd, 2005b: 145).

Şartlı transferlerde ise bütçe doğrusu, şartsız transferlere göre farklılık gösterir. Şartlı transferde transfer miktarının sadece $X$ için harcanması öngörüldüğünden ikinci bütçe doğrusu AGD biçiminde olacaktır. Y'nin tüketimi belirli bir noktaya kadar olabilecektir ve bu nokta ilk bütçe doğrusunda $Y$ tüketiminin maksimum olduğu yerdir. Transfer nedeniyle medyan seçmende gelir etkisi ortaya çıkmıştır. Ortaya çıkan gelir etkisi nedeniyle gelirin bir kısmını X'e bir kısmını Y'ye ayırmıştır. Şekilde Y ekseni diğer tüm özel ve kamusal malları içermektedir. Şartlı transferin gerçekleşmesi durumunda diğer kamusal malların tüketimi artar. $Y$ eksenin sadece özel firmalarca üretilen mallardan ibaret olduğu düşünülürse ek $Y$ kamusal harcama yapmak yerine yerel vergilendirmede bir azalma meydana gelmiştir. Sonuç olarak $Y^{\prime}$ nin $Y_{1}^{\prime}$ den $Y_{2}^{\prime}$ ye kayması, yerel vergilemede bir azalma ve yerel birim tarafından sunulan diğer çıktılarda bir artış anlamına gelir (Bailey, 1999: 187).

Mali eşitlemeye yönelik şartsız transferler idareler arası rekabetin oluşmasına ve dolayısıyla etkinliğin artmasına yardımcı olabilir (Oates, 1999: 1127). Ancak bazı iktisatçılara göre, mali eşitleme programları yoksul bölgelerin ekonomik gelişimini sekteye uğratabilir (Oates, 1999: 1129).

Şartlı transferler, genel olarak idareler arası mali kapasite eşitsizliği sorununa çözüm getirici bir fonksiyona sahip değildir (Due \& Friedlaender, 1977: 465). Şartlı transferler, belirli kamusal mal ve hizmetlerin minimum standartlarda üretilmesini sağlamak amacıyla kullanılabildiği gibi daha çok erdemli mal üretiminin teşviki ve dışsallıkların içselleştirilmesi amacıyla da kullanılmaktadır (Bailey, 1999: 180). Şartlı transferler, sadece veriliş amacına uygun olarak kullanılabilen fonlardır. Bu tür fonların özelliği belediye hizmetleri, eğitim, sağlık, bayındırlık gibi belirli fonksiyonun üretimine özgülenmiş olmasına bağlıdır. Şartlı transferler, yerel birimlere aktarılan kaynak önceden tespit edilmiş bir miktardır ve yardım olarak aktarılacak kaynağın iktisadi dalgalanmalardan etkilenmesi söz konusu değildir ${ }^{6}$. Teoriye göre, kamusal harcamalar hibe miktarını aşamaz. Ancak pratikte özellikle altyapı gibi harcamalarda hibe miktarının aşılabildiği görülmektedir. Belirli bir harcama sonucu hibe miktarının tamamı kullanılmamışsa kalan miktar başka bir kullanıma yönlendirilebilir. Şartlı transferlere bağlı harcamalarda artış, bir önceki dönem yapılan söz konusu harcamalar ile hibe arasındaki marjinal farklılık kadar olur (Litvack \& Seddon, 2004: 27). Şartlı transferler, yerel birimlerin kamusal mal üretimindeki önceliklerini saptırır. Şartlı transferler yerel birim bütçesinin büyük bir kısmını teşkil ediyorsa kamusal malları kendi öncelikleri doğrultusunda üretemeyecek, transfer hangi koşula bağlandıysa o alanlarda faaliyete girişecektir.

\footnotetext{
${ }^{6}$ Bu tür kaynak aktarımının kararı çoğu zaman politik bir karar alma sürecini gerektirdiğinden merkezi yönetim ile yerel birimler arasında pazarlık sebebi olmaktadır. Merkezi yönetim, yerel birimlerin kendi politika öncelikleri doğrultusunda faaliyette bulunmalarını sağlar.
} 
Eşleme (oransal) transferi, şartı transferlerin bir alt kategorisi olup yerel birimle maliyet paylaşma programıdır. Özel bir amaç için fon kullanılır ve belirli bir dereceye kadar kullanıcı yerel birim hizmetine yardım edilir. Eşleme transferi genellikle fayda taşmaları nedeniyle ortaya çıkan maliyetleri gidermek için kullanılır. Eşleme oranının büyüklüğü taşma oranının derecesini yansıtır (Oates, 1999: 1127). Eşleme transferleri, yerel öncelikleri etkiler ve taşma etkisini bertaraf etmede bir çözüm sunar (Litvack \& Seddon, 2004: 30). Eşleme transferleri, merkezi yönetimin transfer konusu hizmete yaptığı katkının türüne bağı olarak açık uçlu veya kapalı uçlu olabilir. Açık uçlu eşlemede, kamu hizmetine harcanan para arttıkça yerel birimlere yapılacak transferin miktarı artar. Kapalı uçlu eşlemede ise yardımın belirlenmiş bir üst sınırı vardır (Ulusoy \& Akdemir, 2007: 101). Eşleme transferleri, yatay eşitsizliğin çözümüne yönelik bir transfer yöntemi değildir. Dahası eşleme transferleri, zengin yörelerle yoksul yöreler arasındaki kaynak dağıımını daha da olumsuz etkileyebilir. Zengin yöreler, eşleme transferinden daha çok yararlanma gayreti içinde olabilirler. Ancak eşleme oranları belirlenerek yöreler arasındaki eşitsizlik sorunu telafi edilebilir. Eşleme (oransal) transferler, yardım yapılmış kamusal mala ilişkin mutlak ve ilgili maliyetlerin azalmasına neden olur ve medyan seçmeni tüketim yapması yönünde cesaretlendirir. Yardım yapılmış kamusal mala ilişkin fiyatlar düştüğünden $Y$ karşısında $X^{\prime}$ 'in tüketimi daha da artar (Şekil 1). İkame etkisi nedeniyle eşleme transferinde bütçe doğrusunun eğimi değişir ve X'e ilişkin maksimum tüketilebilirlik noktası artar (Bailey, 1999: 189). Eşleme transferi, şartlı ve şartsız transferlere göre yerel yönetim harcamalarını daha canlandırıcı etkiye sahiptir. Ancak bireye faydası açısından şartsız transferler, eşleme transferlere göre daha iyidir (Stiglitz, 2000: 747).

\subsection{Transferin Kaynağı}

Merkezi yönetim transfer kaynağını ya tamamen kendi bütçesinden karşılayabilir (paternal yöntem) ya da yerel birimlerin elde ettiği gelirlerin bir kısmını bir havuzda toplayarak (fraternal yöntem) eşit bir şekilde veya az geliri olan yerel birimler lehine (Robin Hood yöntemi) tekrar dağıtabilir (Shah, 2007). Merkezi yönetim, yerel gelirlerin bir kısmının sabit bir vergi oranı ile toplanmasını ve buna bağlı olarak dağıtılmasını öngörebilir veya yerel birimler yerel gelirlerin bir kısmının sabit bir vergi oranı ile toplanmasını kararlaştırabilir. Uygulamada sık görülen eğilim, bir paternal yöntem olan gelir paylaşım yöntemidir. Ancak pek çok gelişmekte olan ülkede gelir paylaşım yöntemi sorunlar içermektedir. Ulusal vergi programlarına göre belirlendiklerinden yerellikten uzaktırlar. Gelir paylaşım yöntemi, mali yerelleşmeden beklenen etkinliği azaltır ve hesap verilebilirlik unsurunu yok eder. Çünkü bir bölgedeki vergilerin merkezin eliyle toplandığı bu yöntem, yerel düzeyde meydana gelen fayda ve maliyet arasındaki arzulanan bağı kırar. Gelir paylaşım yöntemi, yerel birimlerin harcama yapma özerkliğini azaltır. Dahası şarta dayalı gelir paylaşım yöntemi ile mali yerelleşme aşınır (De Mello, 2000: 367). Ancak şarta dayalı gelir paylaşımı, saydamlık ve hesap verilebilirlik hususunda olanak sağlar. Şarta dayalı gelir paylaşımı, yerel tercihlerden ve önceliklerden çok, merkezin tercihlerini yansıtır. Aslolan, gelir 
paylaşımında herhangi bir şartın olmamasıdır. Ancak şarta dayalı olmamasının da birtakım maliyetleri vardır. Merkezce gönderilen kaynak etkin kullanılmayabilir ya da harcama tercihlerinde uyumsuzluk nedeniyle merkezi yönetimin elde etmek istediği faydayı azaltabilir.

\section{Transfer Sisteminin Yapısı}

Teoriye göre, aşağıda sayılan karakteristik özelliklerin yerel kamusal mal üretici birimleri arasındaki ideal transfer sisteminde olması gerekmektedir (Litvack \& Seddon, 2004: 29).

- Transfer sistemi objektif bir şekilde açıkça tanımlanmalı ve iyi kurgulanmış bir formüle dayandırılmalıdır. Merkezi yönetim ile yerel yönetim birimleri arasında gizli, siyasi müzakerelere konu edilmemelidir. Transfer sistemi ya sadece merkezi hükümet tarafından ya transfer komisyonu tarafından ya da merkezi ile yerel karar mekanizmalarının bir araya gelmesiyle belirlenebilir.

- Transferler yıldan yıla rasyonel yerel bütçe yapmaya izin vermesi açısından istikrarlı bir yapıda olmalıdır. Ancak transferler, aynı zamanda yeterince esnek yapıda olmadır ki ulusal istikrar hedefleri yerel mali düzenlemeler nedeniyle tehdit altında olmasın. Söz konusu iki hususun sağlanabilmesi için toplam merkezi hükümet gelirlerinin sabit bir oranı her yıl yerel birimlere aktarılmalıdır ve periyodik olarak belirli aralıklarla yeniden müzakere edilmelidir.

- Transfer sistemi için geliştirilen formül saydam olmalı, güvenilir faktörler tespit edilmeli ve mümkün olduğunca basit olmalıdır. Gelişmekte olan ülkelerde karmaşık formüller uygulanabilir veya inandırıcı olmayabilir.

- Eğer birkaç hedef için transfer uygulanmak isteniyorsa farklı transfer sistemleri tasarlanmalıdır.

Shah'a (1994) göre, yerel birimler bağımsız hareket edebilme özelliğini sürdürebilmeli ve önceliklerini kendileri belirleyebilmelidir. Transfer programları kısıtlayıcı olmamalıdır. Yerel birimler belirlenen sorumlulukları yerine getirebilecek şekilde gelir yeterliliğine sahip olmalıdır. Tahsis edilen fonlar yerel birimin mali intiyacıyla doğru orantılı, vergi kapasitesiyle ters orantılı olmalıdır. Yerel birimlerin beş yıllık finansal öngörü yapabileceği şekilde transfer sistemi kurulmalıdır. Transfer sisteminin tasarımı, sağlam mali yönetim için teşvikler sağlamalıdır. Transfer sistemi merkezi politikaların olumsuz etkilenmemesini sağlamaya yönelik dizayn edilmelidir Transfer sistemiyle yerel birime gönderilen kaynak farklı sektörlerdeki veya farklı türdeki fonksiyonlardaki kaynak dağılımı eğilimlerini etkilememelidir (Shah, 1994: 45). Transferler, mali özerkliği kısmen zedeleyen bir özelliğe sahiptir. Ancak iyi tasarlanmış bir formül hem mali yerelleşmeyi disipline edici hem de onu tamamlayıcı bir araçtır (Neyaptı, 2005: 107). 
İyi tasarlanmış bir formül, aynı zamanda yerel birimler üzerinde sıkı bütçe kısıtı benzeri bir sınır oluşturur (Neyaptı, 2005: 107). Mali yerelleşmeden beklenen iyi yönetişimin sağlanmasına, sıkı bütçe sınırı sağlayan formül sistemiyle katkıda bulunulur.

Transfer programı, yerel harcama düzeyini etkilemeyecek şekilde dizayn edilmelidir (Due \& Friedlaender, 1977: 461). Ancak bir transfer programının en büyük riski, yerel birimin harcama yönetim özerkliğini azaltması tehlikesidir. Yerel tercihler ve gereklilikler yerini merkezi önceliklere bırakabilir ve transfer programı merkezi idarenin önceliklerini yansıtabilir (De Mello, 2000: 367).

Formüle yerel birimin vergi toplama gayretine dair bir eklenti yapılmalıdır. Çünkü yerel birimin merkezi yönetimden alacağı kaynak, yerel birimin vergi toplama gayretini olumsuz etkileyebilir (Due \& Friedlaender, 1977: 465). Transfer sisteminin yönetiminde yerel birimlere sistemde değişiklik yapma yetkisi verilebilir (Yılmaz, 2003: 12). Söz konusu husus, mali yerelleşme açısından olumlu etki sağlar. Kişi başına düşen gelir ile kişi başına düşen yardım miktarı arasında negatif bir ilişki olmalıdır ki, yatay eşitlemeden söz edilebilsin. Ancak yapılan çoğu ampirik çalışmada tam tersi durumla karşılaşılmaktadır (Hyman, 1990: 661). Kamu tercihi teorisine göre, performans odaklı transfer sistemi ile hesap verilebilir bir yapı oluşturulmalıdır (Shah, 2007: 9). Eşitlik sağlayıcı transfer, serbest göçün yol açtığı dengesizlikleri gidererek ekonomik etkinliğe katkıda bulunur (Petchey, 1993: 354). Transferin şartlı veya şartsız ya da açık uçlu veya kapalı uçlu eşleme yardımı şeklinde olması farklı sonuçlar ortaya koyabilir. De Mello \& Barenstein'a göre (2001), merkezi yönetimden alınan şartsız transferlerin toplam gelir içindeki payı ne kadar büyükse mali yerelleşme ile ekonomik büyüme arasında o kadar pozitif ilişki vardır.

\section{Sonuç}

Yerel yönetimler ekonomisi teorisine göre, yerel sistemde var olan yatay eşitsizliğin çözümü için öncelikle yatay eşitsizliğin tespiti ve ölçümü yapılması gerekir. Bir yerel kamusal mal üretici birimin yatay eşitsiz olduğu ortaya çıkması durumunda bir transfer yöntemine göre söz konusu yerel kamusal mal üretici birimine kaynak aktarılması sağlanmalıdır. Söz konusu kaynak, merkezi hükümet bütçesinden aktarılabileceği gibi yerel kamusal mal üretici birimlerin bütçelerinden oluşturulan bir havuzdan da sağlanabilir. Bunun yanında yerel yönetimler ekonomisi teorisine göre, herhangi bir şarta bağlı olmadan ilgili yerel kamusal mal üretici birimine kaynak aktarımı yapılmalıdır. Sinek kâğıdı etkisi adı verilen söz konusu muhtemel sorun nedeniyle şartsız kaynak aktarımına dayalı transfer sisteminde kamusal harcamalarda meydana gelen artış, yerel topluluğun öz gelirinde meydana gelen artışın etkisinden daha büyük artışa neden olabilir. Söz konusu durumdan sakınılması için, transfer formülasyonu vergi toplama gayreti ile ilişkilendirilebilir. Vergi toplama gayreti daha fazla olan bir yerel birimin prestij yatırımlarına yönelik ödüllendirme kalemi getirilebilir. 
Transfer sistemi vergiler ile kamusal mal tüketimi arasındaki bağı kopartır. Çünkü transfer odaklı yerel yönetim harcama sistemlerinin kurulması, yerel yönetimler ekonomisinin temel nüvesi olan vergi-yerel kamusal mal tüketimi ilişkisini zedeler. Bu durumda vergi-fiyat ile yerel kamusal mal odaklı kamu ekonomisi pratikte kurulamaz. Yerel kamusal mal üretimi, yerel mükellefin vergilendirilmesi ile gerçekleşmediğinden siyasi aktörlerin sorumluluğu da ortadan kalkar. Söz konusu durum, Kamu Tercihi Teorisi açısından kamu ekonomisinde etkinsizliğin bir nedeni olarak gösterilir. Kamu Tercihi Teorisi'ne göre, yatay eşitsizliği giderici ya da azaltıcı kamu politikasını benimsemiş kamu ekonomisinde böylelikle birtakım yeni etkinsizlik sorunlarıyla karşılaşılır. Kamu Tercihi Teorisi, birçok kurumsal bileşenden yoksun bir yatay eşitsizlik çözücü kamu politikasının mükemmel sorun çözücü olmadığını ileri sürer. İlgili kamu politikasının kamu ekonomisinde etkinliğinden bahsedebilmek için uygun kurumların inşaası gerekir. Dahası transfer sistemi, toplanan yerel vergi miktarının azalması ve yerel kamusal mal üretiminin artmasına yol açacağından etkin olmayan bir kamu ekonomisi ortaya çıkar.

Kamu Tercihi Teorisi'ne göre kendi çıkarlarını düşünen yerel kamusal mal üretici birimleri transfer sistemini kötüye kullanabilirler. Transfer sisteminde, yerel kamusal mal üretici birimlerini bağlayıcı herhangi bir düzenleme olmadığı sürece asimetrik bilgi sorunlarıyla karşı karşıya kalınabilir. Herhangi bir yerel birimin transfer sistemini kötüye kullanması ahlaki tehlike içermektedir. Yerel birimler, kaynağı kullanma konusunda gereken hassasiyeti göstermeyebilir ve etkin olmayan bir kamusal harcama gerçekleştirebilir. Kaynak aktarımı yapıldığı halde bir yerel kamusal mal üretici birimi için yatay iyileşme sağlamaması halinde yerel birimi cezalandırıcı yani uygulama yaptırımını içeren formül kaleminin var olması gerekmektedir. Bu husus, bir kontrol mekanizması işlevi görür.

Transfer sistemi kurgulanırken transfer sisteminin ekonomik yansımaları da dikkate alınmalıdır. Transfer mekanizması, yerel düzeyde finanse edilmeyen bir yerel faaliyetin yanlış fiyat sinyalleri vermesine ve söz konusu yöre piyasasının olması gerekenden farklı dengelenmesine neden olabilir.

Eşitlik odaklı formülde ulusal merkez haline gelmiş yerel birimlere görece daha az kaynak aktarılmalıdır. Böylece idareler arası eşitlik kurulabilir. Mali yerelleşme düzeyini olumlu etkileyen transfer sistemi tasarlanmalıdır. Bu yüzden şartsız transferler, şartlı transferlere tercih edilmelidir. Ancak bu durumda, idarelerarası transfer sistemi kurgulamak yerel kamu üretici birimleri arasındaki yarışı olumsuz etkileyebilir çünkü yerel vergiler ve harcamalar ülke içinde daha homojen hale gelebilir. Bu etkiyi bertaraf etmek zordur.

Eşitlik sağlayıcı transfer sistemi makroekonomik dengeleri olumsuz etkilemeyecek şekilde dizayn edilmelidir. Kamusal harcamalarda konjonktürel artışlara neden olmayacak bir hibe havuzu tasarlanmalıdır. Bu yüzden, birkaç vergi türünden oluşan bir havuz yerine geniş tabanlı bir havuz tercih edilmelidir. Makro değişkenleri etkilememesi için transferler, merkezi yönetimce bazı özel koşullara dayandırılabilir ancak özellikle eşitlik sağlayıcı transferlerde özel şartların varlığı istenmemektedir. 
Yerel harcamaların maliyetleri, vergi mükellefi-tüketiciler tarafından algılanamadığından mali yerelleşme sürecine olumsuz etkide bulunabilir. Transfer yöntemiyle, faaliyetler merkezden finanse edildiği için, yerel ihtiyaç ve tercihlere yeterince cevap veremeyebilir. Yerel harcama faaliyetlerinin içselleştirilmesi söz konusu olamadığından kaynak tahsisinde etkinliğe ve hesap verilebilirlik hususuna olumlu katkıda bulunulamaz. Transfer sistemi, yerel üretici birimin ürettiği bir kamusal malın finansmanına tüm ülke halkının katılmasına yani mali illüzyona neden olur. Bu etkiyi bertaraf etmek oldukça zordur.

Transferle yerel birimlere gönderilen kaynak, yatay eşitsizlik özelliği gösteren yerel birimlerin, yatay eşitsizlik düzeyinin daha da artmasına neden olabilir. Böyle bir durumda düşük gelirli bölgelerin merkezi yönetime daha fazla bağımlı hale gelmesi söz konusu olur. Yerel birimler arasındaki mali uyumsuzluğun daha fazla derinleşmesi, mali göç mekanizmasını da olumsuz etkiler. Daha kaliteli kamusal mal üreten alanlara göç etmesi gereken iktisadi ajanlar, yerlerinde kalabilirler. Yatay eşitsizliğe sahip ancak coğrafi ve iktisadi açıdan potansiyele sahip yöreler göç alırsa transfer sisteminden gelen kaynak, mali yerelleşme açısından olumlu sonuçlar doğurabilir.

Transfer sisteminde geliştirilecek formülde gelişmişlik endeksine yer verilmelidir. Diğer bir deyişle, yatay eşitlemeden söz edilebilmesi için, söz konusu yerel kamusal mal üretici biriminde kişi başına düşen gelir ile kişi başına düşen yardım miktarı arasında negatif bir ilişki olmalıdır. Diğer yandan, transfer sisteminin yönetiminde yerel birimlere aktif rol verilerek gerektiğinde sistemde değişiklik yapma yetkisi getirilebilir. Söz konusu husus, mali yerelleşme açısından olumlu etki sağlar.

\section{Kaynakça}

Bailey, J.S. (1999). Local Government Economics, Macmillan Press Ltd, London.

Bruce, N. (2001). Public Finance and the American Economy, Addison Wesley, Boston.

Dahlby, B. (2011). "The Marginal Cost of Public Funds and the Flypaper Effect", Int Tax Public Finance, 18, 304-321.

Due, J.F. \& Friedlaender, A.F. (1977). Government Finance Economics of the Public Sector, Sixth Edition, Richard D. Irwin Inc.

Grossman, P.J. (1987). "A Political Theory of Intergovernmental Grants", The University of Adelaide, Working Paper 87-6.

Holcombe, R.G. (2006). Public Sector Economics: The Role of Government in the American Economy, Pearson Education.

Hyman, D.N. (1990). Public Finance, The Dryden Press, Chicago.

Ladd, H.F. (2005a). "Fiscal Disparities", The Encyclopedia of Taxation And Tax Policy (Ed.) Cordes J.J., Ebel R.D., Gravelle J.G., The Urban Institute Press, Washington. 
Ladd, H.F. (2005b). "Fiscal Equalization", The Encyclopedia of Taxation And Tax Policy (Ed.) Cordes J.J., Ebel R.D., Gravelle J.G., The Urban Institute Press, Washington.

Litvack, J. \& Seddon, J. (2004). Desantralization Briefing Notes, World Bank Institute.

Ma, J. (1997). Intergovernmental Fiscal Transfer: A Comparison of Nine Countries, World Bank.

Martin, R. \& Sunley, P. (1998). "Slow Convergence? Post-Neoclassical Endogenous Growth Theory and Regional Development", Economic Geography, 74, 201-227.

Musgrave, R.A. (1959). Kamu Maliyesi Teorisi, (Çev.) O. Şener \& Y. Methibay, Asil Yayın Dağıtım, Ankara.

Neyaptı, B. (2005). "Mali Yerelleşme Aracılığı ile Mali Eşitleme”, Mali Yerelleşme: Yoksulluk ve Bölgesel Eşitsizlik Sorunlarının Çözümü Için Yeni Yaklaşım, TESEV Yayınları, İstanbul, 104-127.

Oates, W.E. (1999). "An Essay on Fiscal Federalism", Journal of Economic Literature, September, 37(3), 1120-1149.

Oates, W.E. (2006). "The Many Faces of Tiebout Model, The Tiebout Model at Fifty" (Ed.) Fischel W.A., Cambridge MA, Lincoln Institute of Land Policy, 21-45.

Özel, M. (2009). “Avrupa Birliği'ne Uyum Sürecinde Türkiye'de Bölgelerarası Dengesizlik ve Yeni Yönetsel Birim Arayışları", Ankara Üniversitesi SBF Dergisi, 64(01), 165-199.

Öztürk, L. (2006). “Geçiş Ekonomilerinde Bölgelerarası Dengesizlikler: Bir Neden Olarak Piyasa Ekonomisi", Manas Üniversitesi Sosyal Bilimler Dergisi, 16, 21-35.

Sağbaş, i. \& Bağdigen, M. (2003), Local Government Finance in Turkey, İstanbul Metropolitan Municipality, Directorate for Research.

Shah, A. (2007). "A Practitioner's Guide to Intergovernmental Fiscal Transfers", Intergovernmental Fiscal Transfers (Ed. Boadway, R. \& Shah, A.)

Stiglitz, J.E. (2000). Economics of the Public Sector, W.W. Norton Company, New York.

Tekeli, R., Acartürk, E. \& Görmüş, Ş. (2005). "Idarelerarası Mali Yardım Dağıtım Sisteminin Yeniden Yapılandırılması ve Bütçenin Mali Yardım Yoluyla Türkiye'de Bölgelerarası Eşitsizliğe/Gelir Dağııımına Etkisi”, 20. Türkiye Maliye Sempozyumu, 23-27 Mayıs 2005, Denizli.

Ulusoy, A. \& Akdemir, T. (2007). Mahalli idareler, Seçkin Yayınevi, Ankara.

Uzay, N. (2005). Bölgesel Gelişmişlik Farklarının Giderilmesi ve Bölgesel Kalkınma Ajansları, Seçkin Yayınları, Ankara.

Yılmaz, S. (2003). "Intergovernmental Transfers: Concepts and Policy Issues", World Bank Institute, WB177898. 